\title{
Digestion and metabolism of dietary fat in farm animals
}

\author{
BY MICHEL DOREAU AND YVES CHILLIARD \\ Institut National de la Recherche Agronomique, Laboratoire Sous-Nutrition des Ruminants, Theix, \\ 63122 Saint Genès Champanelle, France \\ Fat digestion and metabolism differ widely between animal species. In ruminants, dietary fats are \\ hydrogenated in the rumen before intestinal absorption so that absorbed fatty acids (FA) are more \\ saturated than dietary FA. In non-ruminants, intestinal FA digestibility depends on the level of \\ saturation of dietary FA. Fat supplementation of the diet of cows decreases milk protein and has a \\ variable effect on milk fat, depending on the source of dietary lipids. When encapsulated lipids are \\ used, the linoleic acid content of milk is increased, but the organoleptic quality of milk may be \\ altered. Supplementary lipids are incorporated into non-ruminant body fat, whereas de novo \\ lipogenesis is reduced. There is a close relationship between the nature of dietary FA and non- \\ ruminant body FA.
}

Lipids: Fat digestion: Fat metabolism

Fats are present in small amounts (less than $50 \mathrm{~g} / \mathrm{kg} \mathrm{DM}$ ) in most natural feedstuffs available for animal feeding, except oilseeds. However, supplemental fats are used in diets for nutritional or economic reasons in order to increase the level of fat in diets. Due to their high energy value, fat supplements may contribute to meeting the energy requirements of animals; furthermore, it may be cheaper in some circumstances to provide energy as fat rather than carbohydrates. It is often questioned whether the dietetic value and/or the quality of products, especially milk and meat, are altered by fat supplementation. The answer evidently depends on the type of production. The action of dietary fat is highly dependent on the animal species. Due to digestive and, to a lesser degree, metabolic utilization, the relationships between fat in the diet and fat in the products are different in single-stomached animals and in ruminants, in young and adult animals. In the present article some viewpoints on the digestion and the metabolic utilization of fats are developed in ruminants, and outlined in pigs and poultry. The main consequences in terms of chemical composition and quality of milk and meat are given in the last sections.

\section{TRANSFORMATIONS AND ACTIONS OF DIETARY FATS IN THE RUMEN}

The digestive utilization of fats by ruminants is characterized by events in the rumen before they are absorbed in the intestine. During their stay in the rumen, fats are transformed so that the amount and composition of fat leaving the rumen differ from intake. Moreover, fat has negative effects on ruminal activity, mainly on carbohydrate degradation. In this section, the main features of fat metabolism and interaction with carbohydrate digestion are presented. The interaction between fat and $\mathrm{N}$ metabolism, of moderate magnitude (Doreau \& Ferlay, 1995) is not treated here.

\section{Lipolysis and hydrogenation, synthesis and incorporation of fatty acids by bacteria}

Dietary lipids are extensively hydrolysed in the rumen, by microbial enzymes originating first from different classes of bacteria (of which the best known is Anaerovibrio lipolytica), 
second from protozoa (Harfoot \& Hazlewood, 1988). These enzymes are lipases, galactosidases and phospholipases, and lead to the formation of free fatty acids (FA), without intermediate compounds such as mono- and diacylglycerols. This lipolysis is very rapid, in vitro as well as in vivo (Demeyer \& Van Nevel, 1995). Some factors have recently been found to decrease lipolysis, such as antibiotics (Van Nevel \& Demeyer, 1995) and low pH (Van Nevel \& Demeyer, 1996a). This latter factor explains why lipolysis is reduced with diets rich in starch (Gerson et al. 1985).

Hydrogenation occurs on free FA. Thus it is necessary that lipolysis has taken place previously. The first step is an isomerization. Hydrogenases allow the reduction of FA according to different pathways described by Harfoot \& Hazlewood (1988). The endproduct of hydrogenation of C18 FA is stearic acid. However, when large amounts of linoleic acid are available, hydrogenation generally stops before this final step, leading to various cis and trans isomers of monoenoic FA (Harfoot et al. 1973). The most important is trans-vaccenic acid (18:1n-7). Hydrogenation of polyunsaturated C20 and C22 FA has been discounted by Ashes et al. (1992) but other results show extensive hydrogenation of these FA in vivo (Doreau \& Chilliard, 1997) and in vitro (C. J. Van Nevel and D. I. Demeyer, unpublished results). Hydrogenation generally takes place at a slower rate than lipolysis, but few polyunsaturated FA are present in the rumen.

Bacteria incorporate FA, but are also able to synthesize a wide variety of FA, those with 15 and $17 \mathrm{C}$ atoms being the more characteristic. Synthesis occurs mainly from volatile FA; branched-chain FA arise from isobutyrate and isovalerate. Bacterial cis and trans monounsaturated FA may result from desaturation of saturated FA. Linoleic acid can also be synthesized (Demeyer \& Hoozee, 1984). The extent of this de novo synthesis is lower than the extent of dietary FA incorporation and decreases when ruminal FA concentration increases (Demeyer et al. 1978). Protozoa (Emmanuel, 1974) and fungi (Kemp et al. 1984) can also incorporate and synthesize FA. Synthesized and assimilated FA are esterified as phospholipids and sterol esters (Demeyer et al. 1978), and constitute structural lipids. When large amounts of FA are fed, they are stored as free FA in cytosolic droplets (Bauchart et al. 1990b). These droplets are especially rich in linoleic acid which thus escapes hydrogenation.

\section{Quantitative and qualitative ruminal balance of fatty acids}

It is generally thought that the duodenal flow of FA is higher than FA intake. This idea is supported by the occurrence of ruminal synthesis of FA, whereas, in theory, no degradation or absorption takes place. Recent results have shown that in some circumstances negative balances occur, i.e. duodenal FA flow is lower than FA intake (Doreau \& Ferlay, 1994; Fig. 1). Taking into account all data, including those with protected lipids, a relationship is found between FA duodenal flow (FAD, g/kg DM intake) and FA intake (FAI, g/kg DM intake):

$$
\mathrm{FAD}=0.801 \mathrm{FAI}+9.29(n 113, r 0.87) .
$$

Authors who obtained negative balances first supposed that this was a bias due to the lack of accuracy of measurements of duodenal flows. Now it can reasonably be supposed that degradation and/or absorption occur, contrary to the prevalent idea. Experiments using labelled FA have shown that ruminal absorption and degradation of FA are negligible (Wood et al. 1963). However, Goosen (1975) observed that ruminal absorption of FA increased with FA concentration. On the other hand, it has been shown in vitro that FA can be catabolized to ketone bodies by the rumen epithelium (Cook et al. 1967). Oxidative 


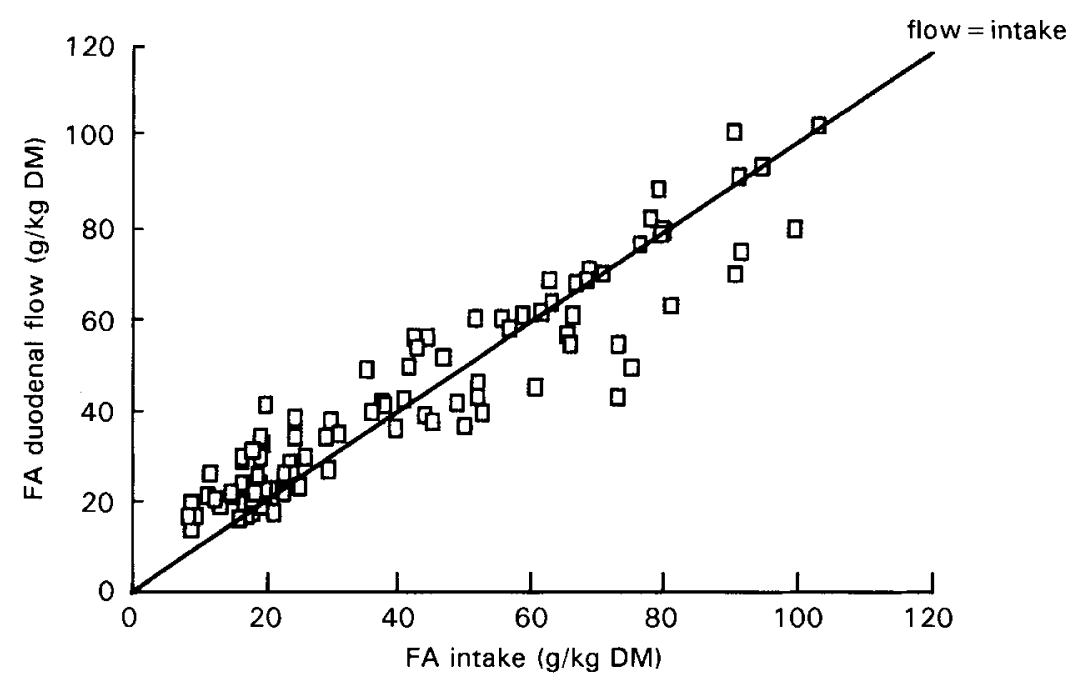

Fig. 1. Relationship between fatty acid (FA) duodenal flow and FA intake in ruminants. (Modified from Doreau \& Ferlay, 1994.)

degradation can also occur from rumen-adherent bacteria which take $\mathrm{O}_{2}$ from epithelial cells (Cheng \& Costerton, 1980). Negative FA balances occur mainly with high-fat diets and with diets based on fresh grass. It can be hypothesized that with high-fat diets some FA are not adsorbed onto feed particles and move towards the rumen wall where degradation and/or absorption take place. At the same time, when large amounts of FA are fed, microorganisms reduce their rate of FA synthesis (Demeyer et al. 1978).

Due to hydrogenation processes, the composition of FA leaving the rumen is very different from the composition of dietary FA. Fig. 2 (Doreau \& Ferlay, 1994) shows from in vivo determinations the percentage hydrogenation of linoleic and linolenic acids, having mean values of 80 and $92 \%$ respectively. No relationship appears between the percentage hydrogenation and total FA intake, or individual FA intake. However, within-experiment results show trends to a lower percentage hydrogenation with diets low in linoleic acid (Bauchart et al. 1990a). Curiously, the extent of hydrogenation is only slightly lower for lipids of forages than for free oils (Ben Salem et al. 1993). All cases of hydrogenation lower than 60 and $70 \%$ for linoleic and linolenic acids, respectively, correspond to diets containing more than $70 \%$ concentrates. This suggests that factors related to high intake of concentrates are the main factors which are able to reduce hydrogenation. This is consistent with the inhibition of lipolysis by low $\mathrm{pH}$. It can be supposed, therefore, that the limitation of lipolysis is the cause of the reduction of hydrogenation.

\section{Effects of fats on carbohydrate digestion}

Lipid supplementation of diets often leads to a decrease in the extent of carbohydrate digestion. The magnitude of organic matter ruminal digestion is reduced (Doreau et al. 1997), and this decrease is due to the fibrous fraction, but not to modification of starch digestion (Zinn, 1989). At the same time, the volatile FA pattern is shifted towards an increase in propionic acid and a decrease in acetic and butyric acids, and methanogenesis is reduced. All these modifications generally occur together, and depend on: (1) the amount of fat: generally low negative effects are observed when diets contain less than $50 \mathrm{~g}$ added 

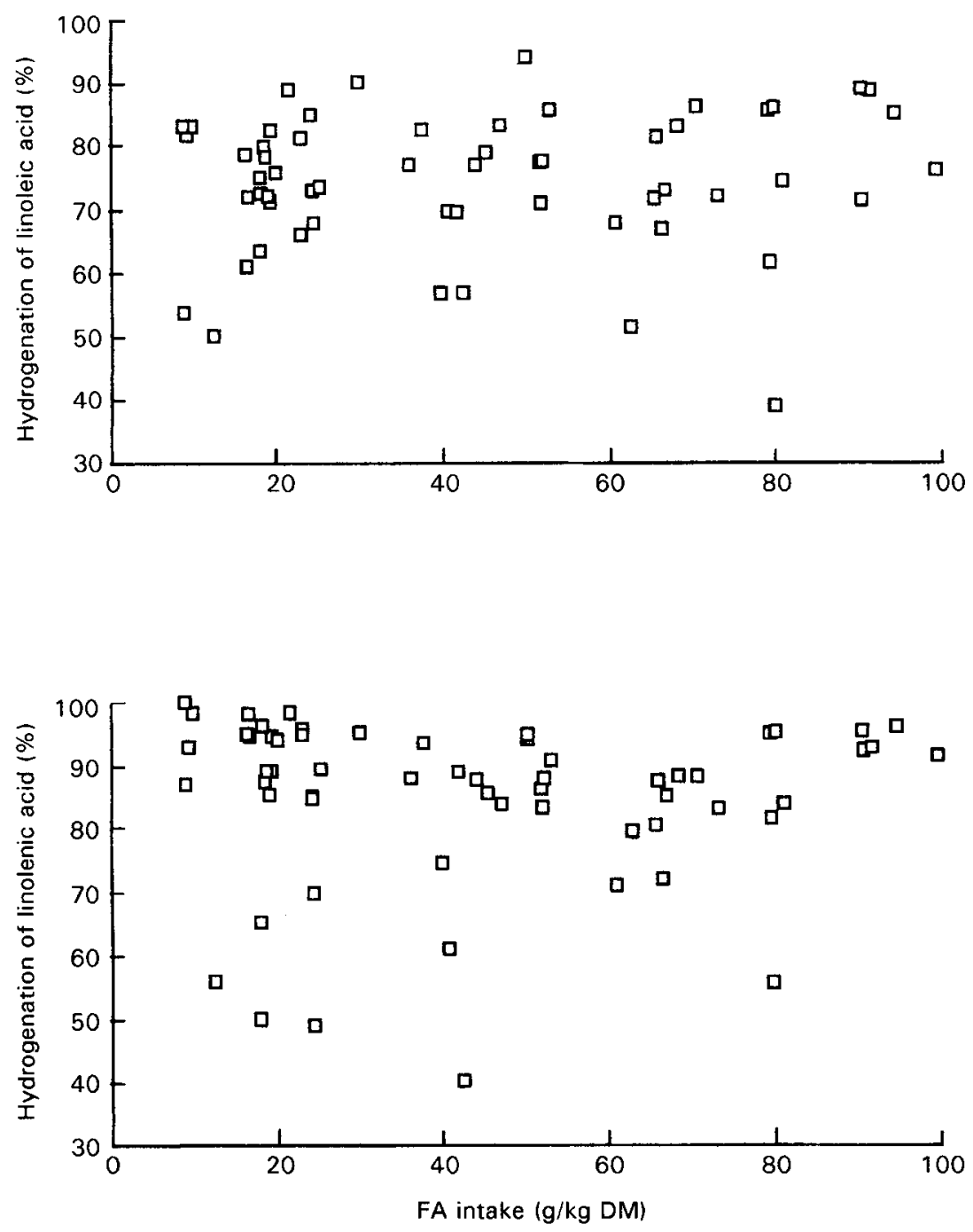

Fig. 2. Ruminal hydrogenation of dietary linoleic and linolenic acids at different levels of fatty acid (FA) intake. (Modified from Doreau \& Ferlay, 1994.)

fat $/ \mathrm{kg}$; (2) the nature of fat: disturbances are the highest for polyunsaturated FA (Palmquist \& Jenkins, 1980; Jenkins, 1993) and especially important for linseed oil, rich in linolenic acid (Ikwuegbu \& Sutton, 1982); as an exception fish oil, rich in polyunsaturated FA with 20 and $22 \mathrm{C}$ atoms, tends to increase digestibility (Doreau \& Chilliard, 1997; Table 1); (3) the nature of the basal diet: fat has less negative effect with diets rich in hay than with diets rich in maize silage (Ben Salem et al. 1993; Smith et al. 1993); the proportion of concentrates in hay diets does not seem to interfere with the disturbances of carbohydrate digestion (Cottyn et al. 1971); (4) the amount of soluble $\mathrm{Ca}$ in the rumen: it has been frequently observed that a supplement of $\mathrm{Ca}$ in soluble form reverses the negative effect of fat on carbohydrate digestion (White et al. 1958); (5) to a lesser extent, the animal species: the disturbances of ruminal digestion may be lower in dairy cows than in sheep (Van der 
Table 1. Effect of a supplement of fish oil $(F O)$ on diet digestibility (Data from Doreau \& Chilliard, 1997)

\begin{tabular}{|c|c|c|c|c|c|}
\hline & \multicolumn{2}{|c|}{ Trial 1} & \multicolumn{3}{|c|}{ Trial 2} \\
\hline & Control & $300 \mathrm{ml} \mathrm{FO}$ & Control & $200 \mathrm{ml} \mathrm{FO}$ & $400 \mathrm{ml} \mathrm{FO}$ \\
\hline \multicolumn{6}{|l|}{ Digestibility (\%) } \\
\hline Organic matter & 72.6 & 75.5 & 69.2 & 72.2 & 73.5 \\
\hline $\mathrm{NDF}$ & 59.4 & 64.5 & 47.0 & 51.8 & $52 \cdot 7$ \\
\hline Propionate in ruminal VFA (mol\%) & 19.4 & 25.0 & 16.4 & 18.5 & 21.5 \\
\hline
\end{tabular}

NDF, neutral-detergent fibre; VFA, volatile fatty acids.

Honing et al. 1981). It is not clear if this can be related to a higher feed intake relative to maintenance requirements in cows than in sheep.

These disturbances are the consequences of modifications in the ruminal microbial ecosystem. It has been demonstrated in vitro that lipids have a negative effect on bacterial growth. This action is more pronounced with polyunsaturated FA than with saturated FA, is reversed by divalent cations such as $\mathrm{Ca}$, and is especially marked on cellulolytic strains (Galbraith et al. 1971; Maczulak et al. 1981). Another effect of fat supplementation is the decrease in protozoal population, which contributes to cellulolysis. This decrease is especially large for polyunsaturated FA; in the case of linseed oil defaunation is almost complete (Doreau \& Ferlay, 1995).

The actions of lipids on the microbial population explain almost all the aforementioned effects. Some other factors may act, such as the competition between bacteria and feed particles for adsorption of FA (Harfoot et al. 1974), which can explain why increasing forages in the diet decreases the interaction between bacteria and FA. The positive effect of Ca may be explained by the formation of Ca salts in the rumen (Palmquist et al. 1986), and it has been demonstrated that lipid supplementation reduces the concentration of ionized $\mathrm{Ca}$ in the rumen fluid (Ferlay \& Doreau, 1995). The lack of Ca can be a limiting factor for the attachment of bacteria to particles (Roger et al. 1990).

\section{Protection of lipids}

Numerous attempts have been made to limit the extent of lipid ruminal hydrogenation and the disturbances of carbohydrate digestion, by different techniques of protection. This means not only the protection of lipids against microbial attack, but also the protection of microbes against the negative effect of lipids. Feeding oilseeds instead of oils gives a slight protection (Jenkins, 1993). Different technological treatments, either physical or chemical, have been developed to improve this protection.

A first method, elaborated 25 years ago, is the encapsulation of an emulsion of oil by formaldehyde-treated proteins. This coating is disrupted in the abomasum, so that intestinal absorption occurs after hydrolysis of triacylglycerols by pancreatic lipase $(E C$ 3.1.1.3). The protection is generally partial, because of the physical action of mastication on the products, and, sometimes, because commercial products are not well treated (Ashes et al. 1979). However, this technique is the only one which allows a large increase in the proportion of polyunsaturated FA in absorbed FA (Hogan et al. 1972). 
More recently, FA have been saponified. This technique was proposed by Jenkins \& Palmquist (1984) because the association of $\mathrm{Ca}$ and $\mathrm{FA}$ as soaps, commonly called salts, was supposed to be inert in the rumen. The absence of perturbations of ruminal digestion with $\mathrm{Ca}$ salts based on palm oil was evident whatever the nature of forages and concentrates (Elmeddah et al. 1991) and was attributed to a low dissociation in the rumen when $\mathrm{pH}$ was between 6 and 7 (Sukhija \& Palmquist, 1990). It has recently been shown (Ferlay et al. 1993; Enjalbert et al. 1994) that Ca salts of unsaturated oils are extensively hydrogenated, suggesting their dissociation when the $\mathrm{pH}$ drops postprandially. This role of $\mathrm{pH}$ was confirmed in vitro by Van Nevel \& Demeyer (1996b). The absence of a negative effect of these salts on carbohydrate ruminal digestion may be due either to a reformation of $\mathrm{Ca}$ salts after they have been hydrogenated, or to a positive action of ionized $\mathrm{Ca}$ by enhancing the adhesion of bacteria to particles.

Fat prills are generally considered as protected fats. A physical treatment (Schauff \& Clark, 1989) is carried out on saturated fats, which have a high melting point, so that they are expected to be inert in the rumen. With such products, ruminal disturbances are generally low or moderate with C16 and C18 FA (Schauff \& Clark, 1989), and with hydrogenated fish oils rich in C20 and C22 FA (Doreau, 1992), but this can be due to the saturation of FA more than to the crystallization. However Sundstøl (1974) observed depressions of crude fibre digestibility with saturated fish oils which have a very high meiting point: the mechanisms of action of these fats in the rumen are not yet well known.

Among the other methods of protection which have been tested, only the chemical linkage of FA as fatty acyl amides (Fotouhi \& Jenkins, 1992; Jenkins, 1995) has shown a rather good resistance to hydrogenation. These techniques are not commercially available.

\section{INTESTINAL DIGESTION AND ABSORPTION OF FATS IN RUMINANTS AND NON-RUMINANTS}

Although the general mechanisms of intestinal lipid absorption are the same for ruminants and non-ruminants, some differences exist, which are in part related to the nature of lipids reaching the duodenum: FA or triacylglycerols. Moreover, the differences of digestibility between the different FA depend on the animal species.

\section{Mechanisms of absorption}

In ruminants, FA reaching the duodenum are mainly adsorbed on feed particles, bacteria and perhaps desquamated cells. Desorption occurs with bile salts and lysolecithins which allow their solubilization in a micellar phase. These micelles allow lipid absorption at the jejunum. In epithelial cells of the small intestine, FA are esterified, triacylglycerols and phospholipids are incorporated into chylomicrons and VLDL (Moore \& Christie, 1984; Bauchart, 1993), which are transported by the lymph and, with diets rich in fat, in part by the portal vein (Chilliard et al. 1992). Absorption and/or microbial synthesis in the large intestine are of low extent (Doreau \& Ferlay, 1994).

In non-ruminants, lipids are emulsified and reach the duodenum as triacylglycerols and phospholipids and, for herbivorous species such as horses, as galactolipids. Biliary salts allow the adsorption of colipase at the lipid-water interface, then the action of the pancreatic enzymes, lipase, esterases and phospholipases. Contrary to the bacterial lipases of ruminants, the action of pancreatic lipase on triacylglycerols releases two FA and a monoacylglycerol in position 2 . These compounds form micelles with biliary salts and are 
then absorbed. After re-esterification in the intestinal cells, transport occurs mainly by the lymph in mammals and, in birds, by the portal system mostly as VLDL (Freeman, 1984).

\section{Intestinal fat digestibility in ruminants}

It is often considered, in ruminants, that fat supplementation increases fat digestibility. This is a consequence of (1) the underestimation of fat intake in diets non-supplemented with fat, in which FA, incorporated in cell structures, are not easy to extract by classical methods, whereas supplemental lipids, which are generally triacylglycerols, are easier to extract; (2) the fact, mentioned earlier, that ruminal FA balance is generally positive with non-supplemented diets and negative with fat-supplemented diets. For this reason, old results obtained by measurement of digestibility between mouth and faeces, are questionable and should be used only to compare the digestibility of different sources of lipids given in the same amounts.

Reliable results have been obtained by measurements between duodenum and ileum or between duodenum and faeces. A survey of sixty-four data points from the literature showed a wide variation in intestinal digestibility, from 55 to $92 \%$. Intestinal digestibility does not depend on FA intake, and the capacity of FA absorption in the dairy cow can be higher than $1 \mathrm{~kg} / \mathrm{d}$ with different sources of fat (Table 2) or with rapeseed oil infused in the duodenum (Chilliard et al. 1991a). From within-experiment comparisons and betweenexperiment values for the same source of fat no clear effect of the FA composition of the diet can be shown: for example, digestibility of soyabean oil varies between $70 \%$ (Hagemeister \& Kaufmann, 1979) and 92\% (Børsting et al. 1992). Methodological errors do not explain these differences, since widely different values are often found in the same experiment. A possible explanation is that micelle formation could depend either on the proportions of the different FA, or on the production of biliary salts which is related to the nature of FA. This hypothesis has not been assessed by experimental data but could explain the observation that the replacement of rapeseed oil by hydrogenated fish oil decreases the digestibility of all FA (Doreau, 1992).

Digestibility depends on chain length (Fig. 3) but does not differ between 16 and $18 \mathrm{C}$ atoms: 79 and $77 \%$ on average respectively. Moreover, digestibility appears to be lower for $\mathrm{C} 20$ and $\mathrm{C} 22 \mathrm{FA}$, but few results are available for these FA. From literature data it can be calculated that the mean digestibilities of $\mathrm{C} 18 \mathrm{FA}$ are $77,85,83$ and $76 \%$ for $0,1,2$ and 3 double bonds (Doreau \& Ferlay, 1994). These results call for two remarks: first, values for 18:3 are of low accuracy due to the very small amounts reaching the duodenum; second, values for 18:1 combine different isomers of which the proportion depends on the nature of dietary FA. More results are required to compare the digestibility of trans and cis isomers.

Table 2. Effect of large amounts of fat on ruminal fatty acid $(F A)$ balance and intestinal $F A$ digestibility (F. Legay, D. Bauchart and M. Doreau, unpublished results)

\begin{tabular}{lcccc}
\hline \hline & & $\begin{array}{c}\text { Rapeseed } \\
\text { oil } \\
(50 \mathrm{~g} / \mathrm{kg})\end{array}$ & $\begin{array}{c}\text { Rapeseed } \\
\text { oil } \\
(100 \mathrm{~g} / \mathrm{kg})\end{array}$ & $\begin{array}{c}\text { Tallow } \\
(100 \mathrm{~g} / \mathrm{kg})\end{array}$ \\
& Control & 835 & 1500 & 1530 \\
FA intake $(\mathrm{g} / \mathrm{d})$ & 290 & 625 & 1235 & 1235 \\
FA digestive flow (g/d) & 365 & 84.5 & 77.1 & 74.6 \\
FA intestinal digestibility (\%) & $89 \cdot 1$ & & \\
\hline \hline
\end{tabular}




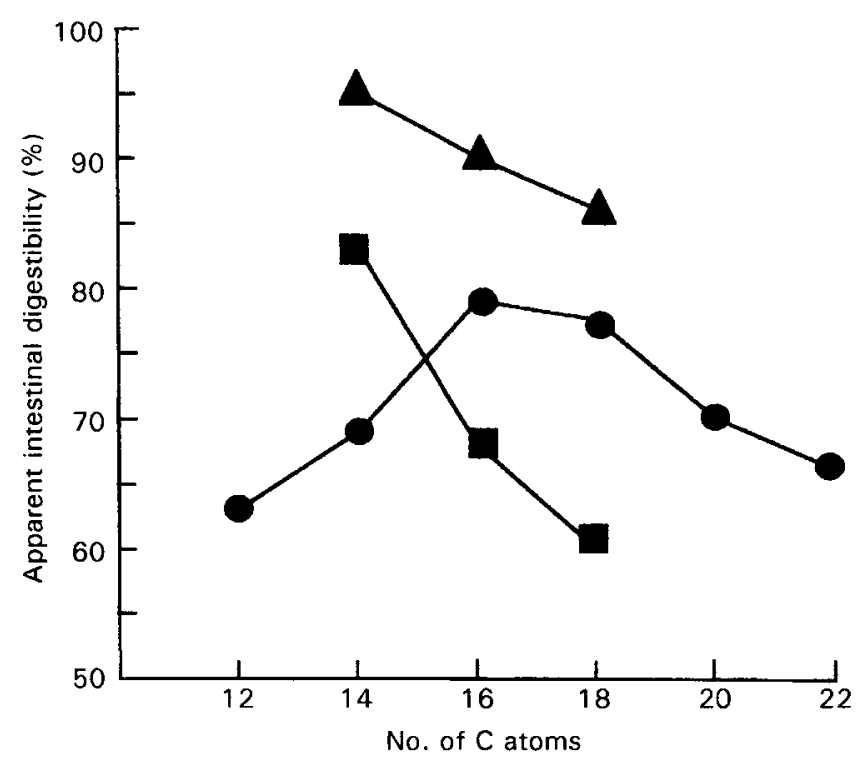

Fig. 3. Effect of carbon chain length on saturated fatty acid digestibility in (O) ruminants (all fats), ( $\boldsymbol{\Delta})$ preruminant calves (all fats except milk) and (ם) poultry (tallow). (Data from Doreau \& Ferlay, 1994; Bauchart \& Aurousseau, 1993; Lessire \& Leclercq, 1982 respectively.)

\section{Intestinal fat digestibility in non-ruminants}

In non-ruminants, digestibility is high; often more than $80 \%$ in pigs and poultry, and more than $90 \%$ in preruminant calves. The effect of FA concentration in the diet on FA digestibility remains unclear. Wiseman (1984) showed a curvilinear increase of diet digestibility when dietary fat is increased, suggesting a limitation of FA digestibility. In contrast, increasing dietary FA increases FA digestibility in pigs (Just, 1982a); this can be attributed in part to the relative decrease in endogenous fat secretion, in part to the high digestibility of added FA. On the other hand, fat digestibility is reduced when fibre in the diet of pigs is increased (Just, 1982b). Lastly, digestibility increases with age in pigs and poultry (Wiseman, 1984).

Digestibility differs between FA, especially in pigs and poultry, moderately in preruminant calves (Bauchart \& Aurousseau, 1993). Digestibility decreases with increasing chain length for saturated acids from 14 to $18 \mathrm{C}$ atoms (Fig. 3). Even digestibility of saturated FA can be very low in young chickens, in which the production of biliary salts is limited (Lessire et al. 1996).

Digestibility increases with unsaturation for C18 FA: 60, 86 and $83 \%$ for 0,1 and 2 double bonds with tallow fed to poultry (Lessire \& Leclercq, 1982). This is due to a lower formation of micelles with saturated FA (Stahly, 1984) which results in an interaction between saturated and unsaturated FA, digestibility being higher when the unsaturated: saturated FA ratio is higher than 1.5 (Table 3). In horses, which consume linolenic acid in forages, the digestibility of this FA is much higher than that of stearic acid (Eilmans, 1991). Moreover, the digestibility of 20:5 and 22:6 from fish oils is very high (Opstvedt, 1984). For the same FA, the digestibility varies according to the position on glycerol: digestibility is higher when saturated FA are esterified in position 2 than in positions 1 or 3, perhaps because apolar free FA are less easily absorbable than the 2-monoacylglycerols (Palmquist, 1988). 


\section{METABOLIC UTILIZATION OF DIETARY FAT}

\section{Effect of fat supplementation on energy value of diets}

The energy value of fats for ruminants is difficult to give with accuracy, because of the negative interactions between lipids and carbohydrate in the rumen. In an attempt to provide an average value, Vermorel et al. (1986) proposed for dairy cows $20.5 \mathrm{MJ}$ net energy $/ \mathrm{kg} \mathrm{DM}$ for fats which moderately decrease carbohydrate digestion. This value came from the observation that, in the literature, the addition of lipids to diets of dairy cows involves low variations of energy digestibility of total diet, so that the high energy value of diets comes from their high gross energy content. This value is consistent with values proposed in other countries. If it is assumed that lipids do not disturb carbohydrate digestion at all (as $\mathrm{Ca}$ salts of palm oil, for example), a higher value can be proposed, reaching $32 \mathrm{MJ}$ net energy/kg FA (M. Doreau, A. Ferlay and Y. Chilliard, unpublished results). This value assumes that the efficiency of metabolizable energy utilization is $80 \%$. It has recently been assessed by Chilliard (1993), from an analysis of the literature (fifteen trials), that the net energy value of $1 \mathrm{~kg}$ of lipids for dairy cows is 23.4 (SD 9.2) $\mathrm{MJ}$, the efficiency of metabolizable energy utilization being on average $81 \%$.

In non-ruminants, the energy value of fats is also difficult to determine, because of the interactions between saturated and unsaturated FA. The apparent metabolizable energy value of lipids varies in the same way as their digestibility because the interactions between lipid and fibre digestibilities are moderate. No matter whether the method of measurement used is direct calorimetry, lipid digestibility or effect on performance, metabolizable energy content is between $30 \mathrm{MJ} / \mathrm{kg}$ for saturated fats such as tallow, and $40 \mathrm{MJ} / \mathrm{kg}$ for vegetable oils, with lard or poultry fat being intermediate (Wiseman, 1984). This energy value is reduced, especially for fats rich in saturated FA, when the level of inclusion of fat increases. The efficiency of use of metabolizable energy for fat deposition is generally greater than $90 \%$ in pigs (Stahly, 1984).

\section{Dietary fat and adipose tissue metabolism}

Fat supplementation increases FA absorption and hence the flux of circulating chylomicrons and VLDL. This generally increases FA uptake by adipose tissue, except when lipoprotein lipase ( $E C$ 3.1.1.34) activity is low, for example in early lactating cows that are in negative energy balance (Chilliard, 1993). The increased flux of exogenous FA within adipocytes results in decreased de novo synthesis of FA from acetate in ruminants.

Table 3. Interaction between basal diet and source of fat: effect of the unsaturated: saturated fatty acid ratio (UFA:SFA) on fat digestibility in pigs (Modified from Stahly, 1984)

\begin{tabular}{llcc}
\hline \hline & & & $\begin{array}{c}\text { Range of fat } \\
\text { digestibility } \\
(\%)\end{array}$ \\
Carbohydrate source & Fat supplement & UFA:SFA & $\begin{array}{c}(\%) \\
\text { Maize }\end{array}$ \\
Barley & Tallow & 1.5 & $70-85$ \\
Maize & Tallow & 4.8 & $90-95$ \\
Barley & Soyabean oil & 4.0 & $90-95$ \\
\hline \hline
\end{tabular}


In the same way, de novo FA lipogenesis from glucose is decreased in pigs (Farnworth \& Kramer, 1987).

In the pig this decrease in FA synthesis is, however, less marked when dietary fat is rich in linoleic acid, which could explain the increase in carcass fatness (Mourot $e t$ al. 1994). Dietary fat can also decrease basal lipolysis (glycerol release), thus increasing fat deposition. However, this trend can be in part compensated for by a decrease in FA reesterification (or an increase in exogenous FA recycling), particularly in response to lipolytic hormones, thus avoiding an excessive enlargement of adipocytes (Chilliard, 1993).

In ruminants, there are no clear differences between the different FA for inhibition of de novo FA synthesis. Few data are available concerning effects of dietary fat on lipolysis. Some results suggest however that $\beta$-adrenergic lipolytic responses can be increased by unsaturated FA. These two events (decreased FA synthesis and increased lipolytic response) could explain why ruminants are less responsive to dietary fat than nonruminants, either for total energy intake, or for increased fatness. This is also suggested by the trend to increased body weight loss in the dairy cow during early lactation, in which dietary fat is largely used by the mammary gland and thus results in higher milk energy secretion (Chilliard, 1993; Fig. 4).

In birds, effects of dietary fats on adipose tissue metabolism are secondary to changes in lipid metabolism in the liver (the main site of FA synthesis in these species). The reduction of dietary carbohydrates when fat is supplied in the diet decreases the de novo synthesis of FA (Hillard et al. 1980) and VLDL secretion by the liver. The proportion of dietary FA in circulating lipids then increases, so that body fat mainly depends on the direct uptake of exogenous FA.

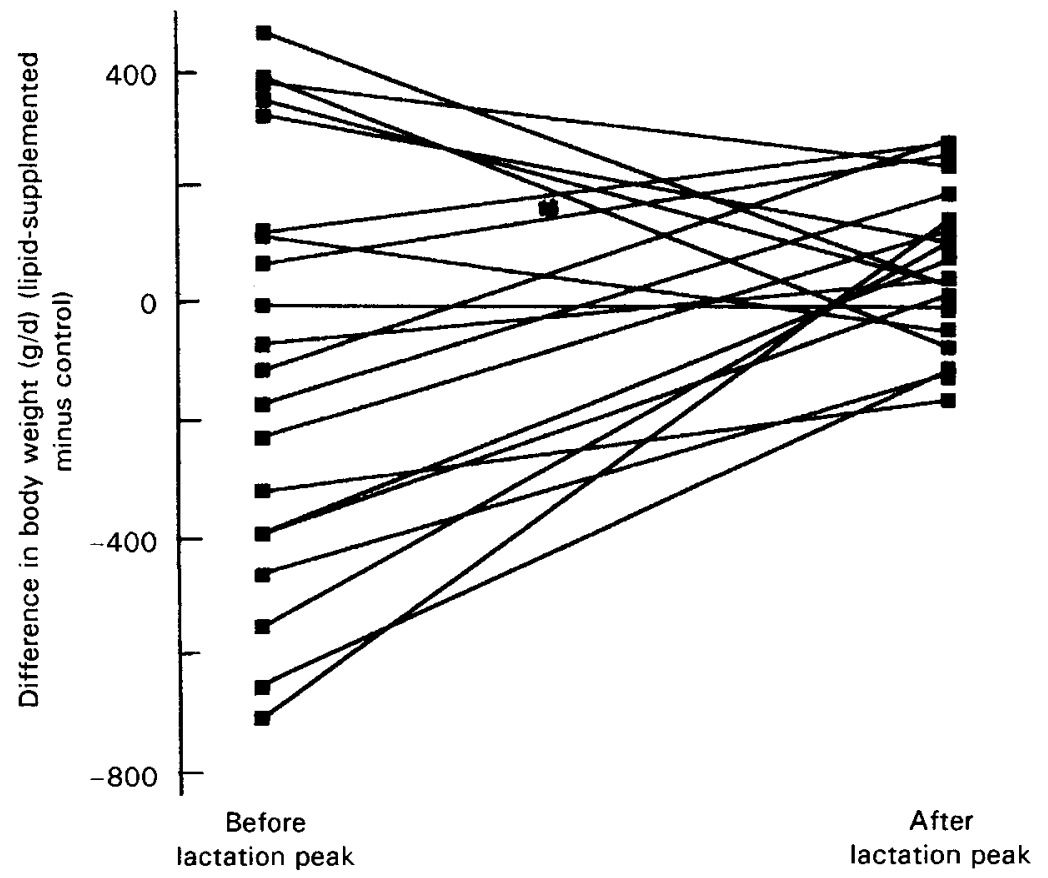

Fig. 4. Effect of lipid supplementation on body-weight change in dairy cows: variation with stage of lactation. (From Chilliard, 1993. Reproduced with the permission of Journal of Dairy Science.) 


\section{CONSEQUENCES OF FAT SUPPLY IN DIETS ON MILK COMPOSITION}

Fat is frequently included in the diets of dairy cows. Some years ago, the aims of fat supplementation were to increase the energy value of the diet and to limit the mobilization of body lipid in early lactation. An increase in milk yield was expected (Palmquist, 1988). Now fat is often considered as a component of the diet and its incorporation into concentrates depends on the price compared with other feedstuffs. One of the factors determining fat supplementation in dairy-cow diets is its effect on milk composition, which has consequences for public health, due to variations in the saturation of FA (Hegsted et al. 1993) and in the amount of trans FA (Willett et al. 1993). In this section are presented the main effects of dietary fat on milk composition and the consequences in terms of milk organoleptic qualities and value for technological transformations.

\section{Milk fat}

Fat supply in dairy-cow diets results in variable effects on butterfat, which can be of high magnitude: sometimes increases or decreases of $10 \mathrm{~g} / \mathrm{kg}$ in butterfat content are observed (Storry et al. 1980). In the literature, the negative effects are approximately the same in number as the positive effects. Saturated fats do not alter butterfat much $(+0.5 \mathrm{~g} / \mathrm{kg}$ on average). Oilseeds reduce butterfat less than free oils $(-0.9 v .-2.8 \mathrm{~g} / \mathrm{kg}$ respectively; Chilliard, 1993). The greatest negative effect is obtained with fish oils: between -5 and $-10 \mathrm{~g} / \mathrm{kg}$ (Chilliard \& Doreau, 1997). With protected fats, the effect of lipid supplementation is positive or negligible: $+6.4,+4.0$ and $+0.4 \mathrm{~g} / \mathrm{kg}$ for encapsulated vegetable oils, encapsulated animal fats and palm-oil Ca salts, at daily mean intakes of 690 , 940 and $590 \mathrm{~g} / \mathrm{d}$ respectively (Chilliard et al. 1993). The effect of dietary lipids on milk fat content tends to be more positive, or less negative, in early lactation than after peak lactation. This is probably due in part to a dilution effect, since milk yield increases less in early lactation, in part due to a higher contribution of dietary lipids to body fat deposition after peak lactation (Chilliard, 1993). Variations in butterfat are the consequences of the specific variations of each milk FA. The addition of lipids to the diet results in a decrease in the secretion and proportion of short- and medium-chain FA in milk. This is due to (1) the usual increase in the proportion of propionate in the ruminal volatile FA mixture, at the expense of acetate and butyrate which are precursors of milk fat; (2) the inhibition of the synthesis of short- and especially medium-chain FA in the udder by long-chain FA (Chilliard et al. 1991b), in particular by FA of trans structure (Banks et al. 1984). At the same time, exogenous FA are transferred to milk and increase the secretion of long-chain FA. When compared with C16 and C18 FA, the rate of transfer is lower for short- and medium-chain FA (Storry et al. 1974) probably because of the transformations which occur in the rumen or in the liver; the rate of transfer is also lower for C20 and C22 FA (Pennington \& Davis, 1975). On rare occasions, for unexplained reasons, lipid supplementation does not modify the mammary uptake of long-chain FA. Adding soyabean oil to a maize silage diet resulted in a reduction in milk fat content of $10 \mathrm{~g} / \mathrm{kg}$ and secretion of C18 FA in milk was reduced from 350 to $313 \mathrm{~g} / \mathrm{d}$ (M. Doreau \& Y. Chilliard, unpublished results).

Milk butterfat is, thus, the result of the balance between the decrease in de novo synthesis and the increase in preformed FA uptake. The large increase in butterfat with encapsulated oils is due to (1) little reduction of precursors of de novo synthesis, because of the partial protection, (2) the lower inhibition of de novo synthesis by polyunsaturated FA compared with products of hydrogenation and (3) the absence of a dilution effect because these lipids generally do not increase milk yield. However, knowledge of the effect of the 
nature of FA on the extent of inhibition of de novo synthesis and of mammary FA uptake remains to be improved. For many sources of dietary fat it is always difficult to predict the variation of butterfat.

In ewes, lipid supplementation always results in a significant increase in butterfat, by 8-22 g/kg (Chilliard \& Bocquier, 1993; Table 4). All supplementations have been made with $\mathrm{Ca}$ salts of palm oil, so that it is difficult to extend this trend to all kinds of fat supplements. In goats, lipid supplementation results in an increase in butterfat, by $2-14 \mathrm{~g} /$ $\mathrm{kg}$. The increase is observed with all kinds of fat, is proportional to fat intake, and is more marked in early lactation than in mid- or late lactation (Chilliard \& Bocquier, 1993). Mare milk fat content does not appear to be related to fat intake, but milk FA composition is related to the nature of dietary FA, for example mares fed on forages produce a milk rich in linolenic acid (Doreau \& Boulot, 1989).

\section{Milk protein}

An increase in the fat content of ruminant diets usually results in a decrease in milk protein content. This trend is general in cows after peak lactation, whatever the source of lipids (Wu \& Huber, 1994), however the decrease seems to be lower with encapsulated oils than with encapsulated animal fats, the latter resulting in a higher milk yield (Chilliard et al. 1993). The decrease in milk protein content occurs as soon as fat is added to the diet; the magnitude of the decrease for the same increase in dietary fat content may be lower at high fat intakes. In early lactation, the depression in protein content is low with diets rich in fat. This may be related to the very small effect on milk yield in early lactation (Doreau \& Chilliard, 1992; Fig. 5). The decrease in protein content is explained by a decrease in casein content. The average of twenty comparisons showed that the addition of lipids to the diet resulted in the same decrease of $1.6 \mathrm{~g} / \mathrm{kg}$ for protein as well as for casein content (Doreau \& Chilliard, 1992). Neither whey protein nor non-protein $\mathrm{N}$ varies with lipid addition.

A noticeable part of these decreases is explained by the increase in milk yield, total protein output being moderately affected by fat supplementation. As a consequence, Wu \& Huber (1994) attributed the decrease in protein content to the absence of an increase in amino acid uptake by the udder as milk yield increases due to fat addition. However decreases in protein content and output occurred with duodenal infusion of rapeseed oil even when the protein balance was largely positive (Ottou et al. 1995). The addition of protected methionine and/or lysine has a positive effect on milk protein content with diets rich in fat as with classical diets, but no positive interaction is found (Doreau \& Chilliard, 1992) so that a limitation of the uptake of these two amino acids is unlikely. Supplementation with lactose could partially alleviate the drop in protein content

Table 4. Summary of the dairy performance responses to fat supplementation in ruminant species (Data from Chilliard \& Bocquier, 1993)

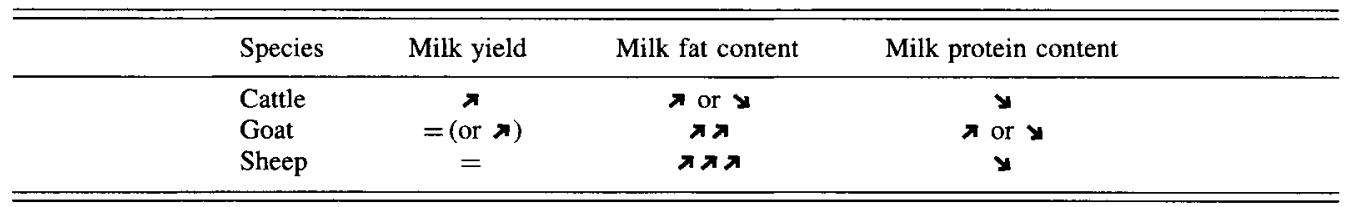




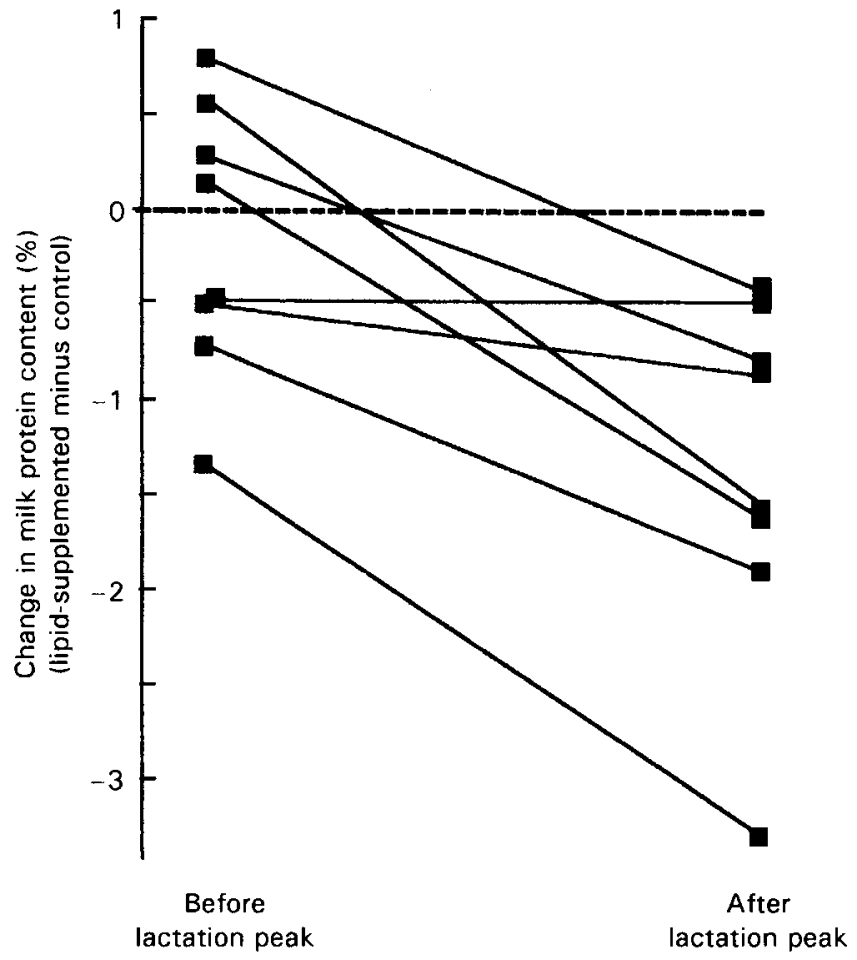

Fig. 5. Effect of fat supplementation of the diets of dairy cows on change in milk protein content with stage of lactation. (From Doreau \& Chilliard, 1992. Reproduced with the permission of INRA Productions Animales.)

(Garnsworthy, 1996). The cause of the limitation of amino acid uptake could be related to hormonal modifications, such as the resistance of mammary tissue to insulin (Palmquist \& Moser, 1981).

In dairy ewes, fat supplementation also results in a decrease in protein content, typically between 0.4 and $3.5 \mathrm{~g} / \mathrm{kg}$. In contrast, no variation has been observed in goats (Chilliard \& Bocquier, 1993; Table 4).

\section{Consequences in terms of technological value and organoleptic quality of milk}

The decreases in protein content, especially in caseins, due to lipid supplementation have negative effects on cheesemaking, in particular on cheese yielding capacity, rennet clotting time, curd firmness and curd firming time (Remeuf et al. 1991; Martin \& Coulon, 1995). With high-yielding cows, milk is often poor in protein even without lipid supplementation, so that cheesemaking problems can occur when supplemental lipids are supplied. Furthermore, when polyunsaturated FA are increased in milk, creams require more chuming time for butter making (Edmondson et al. 1974).

An increase in milk polyunsaturated FA content decreases milk melting point (Palmquist et al. 1993) and leads to a better spreadability of butters at $4^{\circ}$. Despite this, few increases in butter hardness were noted when saturated fats were given to cows, due to the action of mammary desaturase (Wong et al. 1982). 
Lipid addition to dairy-cow diets has often been considered to have a negative effect on the organoleptic qualities of dairy products when milk FA composition is modified. This concerns especially the proportion of linoleic acid. Wong et al. (1973), Edmonson et al. (1974), Badings et al. (1976) and Goering et al. (1976) obtained, by lipid supplementation, milks of which the fat contained up to $30 \mathrm{~g}$ linoleic acid/100 g. They observed: (1) a bland flavour of butter and cheese. The quality of cheeses such as Gouda or Cheddar is considered to be 'acceptable' up to $15 \mathrm{~g}$ linoleic acid/100 $\mathrm{g}$, although they have a soft and floury consistency. Tastes defined as 'oily', 'old fat' or 'stale' were also noted; (2) a trend to butter oxidation, resulting in a deterioration of taste with time. This can be avoided by addition of antioxidants to milk, but not to cow diets. Moreover, oxidation leads to a loss of colour in cheeses.

An 'old fat' taste, without an oxidized taste, has also been observed with milks rich in oleic acid (Middaugh et al. 1988). Almost no problem has been noted with unprotected lipids, which do not increase polyunsaturated FA in milk. On the other hand, feeding oxidized lipids does not have any effect on milk composition and flavour (Cadden et al. 1984).

Among the possible deteriorations of milk organoleptic value, rancidity, which is caused by lipolysis, has been studied. The effects of dietary fat on spontaneous lipolysis have been reviewed by Chilliard (1982). Lipolysis (measured by the concentration of free FA in milk) is increased by diets rich in palmitic acid but not by diets rich in stearic acid or in protected oils which enrich milk in linoleic acid. However, these trends certainly do not seem to have significant consequences on rancidity, since they have never been noted in the literature.

\section{EFFECTS OF FAT SUPPLY IN DIETS ON CARCASS COMPOSITION AND MEAT QUALITY}

The incorporation of lipids into fattening diets is highly dependent on the species. In ruminants, fat supplementation is less practised for meat animals than for dairy animals, perhaps because generally performance is not limited by energy intake. However, the inclusion of fat in the diet generally improves growth in sheep and cattle (Clinquart et al. 1995). Fat supplementation is proposed in piglets after weaning, but can reduce live-weight gain during fattening. In chickens, feedstuffs are generally enriched with lipids to meet the energy requirement (Lessire et al. 1996). The fatty acid composition of meat and/or body fat is especially modified by dietary fat in non-ruminants, with noticeable consequences on meat quality.

\section{In ruminants}

Supplementation of fat in ruminant diets leads to an increase in the proportion of fat in carcasses, whatever the nature of dietary lipids; the weight of all adipose tissues is increased but not the proportion of fat in muscles (Chilliard, 1993; Clinquart et al. 1995). Owing to the hydrogenation of FA in the rumen, the FA composition of body lipids is not modified to a large extent with most lipid sources. However, the saturated: unsaturated FA ratio tends to increase when animal fats are supplied and to decrease when vegetable oils are supplied. Moreover, as fattening diets are generally rich in concentrates, some of the polyunsaturated FA escape hydrogenation. In these conditions the proportions of linoleic and linolenic acid in body fat are increased. In some cases, this increase is of high magnitude, from 2 to $21 \mathrm{~g}$ linoleic acid/100 $\mathrm{g}$ fat in adipose tissues with a supplement of $120 \mathrm{~g}$ encapsulated soyabean-sunflowerseed oil $/ \mathrm{kg}$ diet (Garrett et al. 1976), from 2 to $4 \mathrm{~g}$ linolenic acid $/ 100 \mathrm{~g}$ fat with a supplement of $20 \mathrm{~g}$ lipids $/ \mathrm{kg}$ as unprotected linseeds 
(Clinquart et al. 1991). Fat supplementation generally does not modify tenderness or water retention of muscle (Clinquart et al. 1995). The effect on flavour is variable and opposite results have been obtained with lipids from rapeseed, an improvement by Tesfa et al. (1992) and a degradation by St John et al. (1987). Although no clear effect of the source of lipids is noted, the increase in linoleic acid in fat decreases the flavour score (Ford et al. 1976).

\section{In non-ruminants}

In pigs, the effect of dietary fat on fat deposition does not always result in an increase of fat deposition, due to the negative effect on de novo lipogenesis in the adipose tissue. Fat deposition increases only when ambient temperature is thermoneutral or hot, due to a lower heat production with fat than with carbohydrate. Low temperatures increase fat deposition as a proportion of energy deposited, but this effect is reduced by dietary fat (Stahly, 1984). In pigs, the nature of adipose tissue FA is strongly related to that of dietary FA (Lebret $e t$ al. 1996). In particular, the content of linoleic acid in the different fat tissues is proportional to linoleic acid intake (Wood et al. 1986). Polyunsaturated FA which are characteristic of fish oil (eicosapentaenoic acid and docosahexaenoic acid) can be incorporated into body tissues, unlike $\gamma$-linolenic acid, which does not increase the content of arachidonic acid (Morgan et al. 1992). The effect of polyunsaturated FA on adipose tissue composition can be reversed: the increase in linoleic acid with fattening due to maize oil is reversed when it is replaced by tallow (Courboulay \& Mourot, 1995, cited by Lebret et al. 1996; Fig. 6). Fat is less firm when high levels of linoleic acid are fed (Wood, 1984). However, most lipid sources do not alter pork flavour, even when dietary linoleic acid is high; only fish oil gives an off-flavour of fish (Melton, 1990). Moreover, adding vitamin E to the diet reduces the oxidation of linoleic acid in meat (Mourot et al. 1992).

In poultry, the incorporation of dietary fat does not increase the proportion of body fat, which is mainly determined by the energy:protein ratio in the diet, whatever the source of energy. Due to the reduction of de novo FA synthesis, body fat deposition mainly depends on the direct uptake of preformed FA. For this reason, FA composition of body lipids is highly correlated to the nature of FA intake (Fisher, 1984; Lessire, 1995). For example, the proportion of linolenic acid in body fat of chickens fed with linseed oil can reach $34 \mathrm{~g} / 100 \mathrm{~g}$ instead of $1 \mathrm{~g} / 100 \mathrm{~g}$ with classical diets (Edwards \& Hart, 1971). According to these authors, C20 and C22 polyunsaturated FA are, however, not incorporated in large amounts when fish oil is given. The modifications in FA composition have consequences in terms of carcass texture. With saturated fats in the diet, body fat is 'flaky', whereas with dietary oils rich in oleic and linoleic acids, body fat is 'soft' and 'oily' (Caudron et al. 1993). In extreme cases, meat flavour is negatively modified, especially with fats rich in polyunsaturated FA. Oxidation may be prevented by the use of antioxidants in the diet (Sheehy et al. 1993). The use of fish meal in the diet gives a fish taste to broiler meat, probably due to fish FA (Poste, 1990).

In rabbits, lipid supplementation moderately increases the carcass adiposity. As in other non-ruminants, there is a close relationship between dietary FA and body fat FA. The lipid sources coconut oil and linseed oil significantly alter the organoleptic qualities of meat (Ouhayoun et al. 1987).

In preruminant calves, when different sources of lipids are substituted for maternal milk, the composition of the carcass does not vary, but the composition of deposited FA parallels that of dietary fat (Toullec \& Mathieu, 1969). The increase in meat polyunsaturated FA due to feeding leads to a decrease in consumers' preference (Touraille et al. 1983), although differences are more limited than in pigs or poultry. 


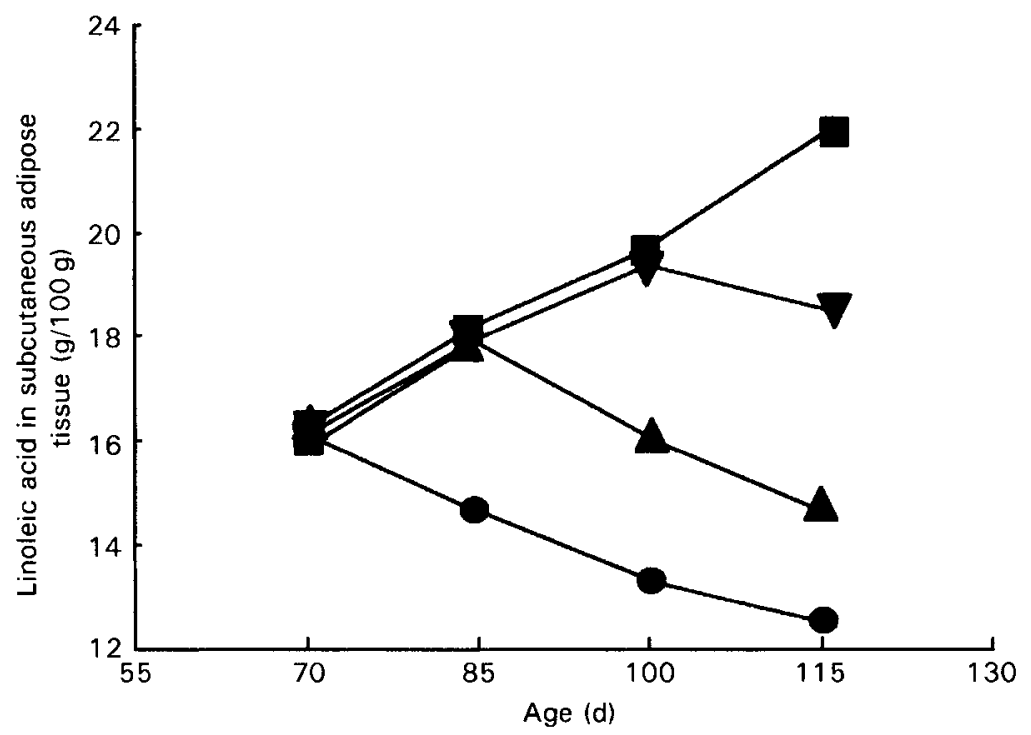

Fig. 6. Effect of lipid source on the proportion of linoleic acid in the adipose tissue of pigs receiving maize oil (M) or

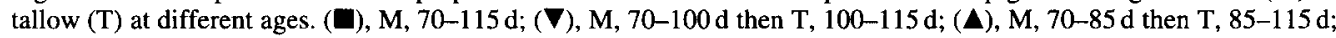
(O), T, 70-115 d. (From Courboulay \& Mourot, 1995, quoted by Lebret et al. 1996.)

\section{CONCLUSIONS}

During the two past decades, the use of fat in the diets of farm animals has been determined by their effect on production, in relation to economic criteria. Various solutions have been proposed to improve the use of fats including, in ruminants, protection of lipids in order to limit the disturbances of carbohydrate degradation, and in non-ruminants, optimization of the unsaturated:saturated FA ratio to increase the energetic efficiency of fats. Now, the need for the improvement of quality and safety of animal products is emphasized by consumers. However, it is difficult to propose ready-made solutions to the producers. The choice between different options is not obvious:

(1) Demands are sometimes antinomic. Modifying the fat content of milk and meat by increasing polyunsaturated FA and decreasing saturated FA is often suggested in order to improve the dietetic value of products. This contributes to a reduction in the organoleptic quality of products. Lowering total fat decreases the taste of meat because intramuscular lipids are reduced; an excess of polyunsaturated FA increases oxidation of products. The recourse to the use of antioxidants in pig and poultry diets is efficient at reconciling these two demands (Noble, 1996), but the use of feed additives is still in debate. For this reason, it is necessary to identify correctly and grade the wishes of the consumers, which can fluctuate rapidly, especially since the power of the media is increasing.

(2) Technological processes offer alternative solutions for the manipulation of animal products. For example, milk can be enriched with polyunsaturated FA in factories (Boudreau \& Arul, 1993) as well as with protein (Mietton, 1991). Manipulation by dietary means is also possible; in the first case encapsulated lipids can be used, in the second case the decrease in protein content due to dietary lipids can be alleviated by the association of lipids with protected lysine and/or methionine. However, the extra cost to the farmer is not compensated for by a higher price of milk, whereas the extra cost for the factory which manipulates milk composition is paid by the consumer. 
(3) The increased demand for products of high dietetic quality can be in contradiction to new recommendations towards the development of extensive systems and the limitation of costs of production, involving a better use of forages. This contradiction is illustrated by a typical case in ruminants: improving the content of $n-3$ and $n-6$ polyunsaturated FA in meat can be achieved by using high proportions of concentrates in the diet and fish-oil supplementation (M. Enser, unpublished results).

These examples clearly show the necessity for the farmers to fit with the market conditions. The role of research is thus to propose innovative and reliable solutions and to contribute to the analysis of the benefits and drawbacks of different feeding strategies.

\section{REFERENCES}

Ashes, J. R., Gulati, S. K., Cook, L. J., Scott, T. W. \& Donnelly, J. B. (1979). Assessing the biological effectiveness of protected lipid supplements for ruminants. Journal of the American Oil Chemists' Society $\mathbf{5 6}$, 522-527.

Ashes, J. R., Siebert, B. D., Gulati, S. K., Cuthbertson, A. Z. \& Scott, T. W. (1992). Incorporation of $n-3$ fatty acids of fish oil into tissue and serum lipids of ruminants. Lipids 27, 629-631.

Badings, H. T., Tamminga, S. \& Schaap, J. E. (1976). Production of milk with a high content of polyunsaturated fatty acids. II. Fatty acid composition of milk in relation to the quality of pasteurized milk, butter and cheese. Netherlands Milk and Dairy Journal 30,118-131.

Banks, W., Clapperton, J. L., Girdler, A. K. \& Steele, W. (1984). Effect of inclusion of different forms of dietary fatty acids on the yield and composition of cow's milk. Journal of Dairy Research 51, 387-395.

Bauchart, D. (1993). Lipid absorption and transport in ruminant animals. Journal of Dairy Science 76, 38643881 .

Bauchart, D. \& Aurousseau, B. (1993). Digestion et métabolisme des lipides chez le veau de boucherie: conséquences sur la composition en lipides des tissus (Lipid digestion and metabolism in the preruminant calf: effects on tissue lipid composition). Viandes et Produits Carnés 14, 172-182.

Bauchart, D., Legay-Carmier, F. \& Doreau, M. (1990a). Relationship between linoleic acid intake and duodenal flows in dairy cows offered lipid supplemented diets. Reproduction Nutrition Development 30, Suppl. 2, 188s.

Bauchart, D., Legay-Carmier, F., Doreau, M. \& Gaillard, B. (1990b). Lipid metabolism of liquid-associated and solid-adherent bacteria in rumen contents of dairy cows offered lipid-supplemented diets. British Journal of Nutrition 63, 563-578.

Ben Salem, H., Krzeminski, R., Ferlay, A. \& Doreau, M. (1993). Effect of lipid supply on in vivo digestion in cows: comparison of hay and corn silage diets. Canadian Journal of Animal Science 73, 547-557.

Børsting, C. F., Hvelplund, T. \& Weisbjerg, M. R. (1992). Fatty acid digestibility in lactating cows fed increasing amounts of protected vegetable oil or saturated fat. Acta Agricultura Scandinavica, Section A, Animal Science 42, 148-156.

Boudreau, A. \& Arul, J. (1993). Cholesterol reduction and fat fractionation technologies for milk fat: an overview. Journal of Dairy Science 76, 1772-1781.

Cadden, A. M., Urquhart, A. \& Jelen, P. (1984). Storage stability of canola-based protected lipid feed supplement and its effect on characteristics of milk and butter. Journal of Dairy Science 67, 1414-1420.

Caudron, I., Castaing, J., Magnin, M., Lessire, M., Barrier-Guillot, B., Bureau, J., Zwick, J. L. \& Messager, B. (1993). Influence de l'incorporation de différentes matières grasses dans l'aliment sur la qualité des carcasses de poulet de chair (Influence of the incorporation of different fats in the diet on carcass quality in broilers). In Quality of Poultry Meat, pp. 93-102 [P. Colin, J. Culioli and F. H. Ricard, editors]. Tours, France: WPSA.

Cheng, K. J. \& Costerton, J. W. (1980). Adherent rumen bacteria. Their role in the digestion of plant material, urea and epithelial cells. In Digestive Physiology and Metabolism in Ruminants, pp. 227-250 [Y. Ruckebusch and P. Thivend, editors]. Lancaster: MTP Press Ltd.

Chilliard, Y. (1982). Variations physiologiques des activités lipasiques et de la lipolyse spontanée dans les laits de vache, de chèvre et de femme: revue bibliographique (Physiological variations in lipase activities and spontaneous lipolysis in bovine, caprine and human milk: a review). Lait 62, 1-31 and 126-154.

Chilliard, Y. (1993). Dietary fat and adipose tissue metabolism in ruminants, pigs, and rodents: a review. Journal of Dairy Science 76, 3897-3931.

Chilliard, Y., Bauchart, D., Gagliostro, G., Ollier, A. \& Vermorel, M. (1991a). Duodenal rapeseed oil infusion in early and midlactation cows. 1. Intestinal apparent digestibility of fatty acids and lipids. Journal of Dairy Science 74, 490-498.

Chilliard, Y. \& Bocquier, F. (1993). Effects of fat supplementation on milk yield and composition in dairy goats and ewes. In La Qualita nelle Produzioni dei Piccoli Ruminanti, pp. 61-78 [G. Enne and G. F. Greppi, editors]. Varese, Italy: Camera di Commercio Industria Artigianato Agricoltura di Varese. 
Chilliard, Y. \& Doreau, M. (1997). Influence of supplementary fish oil and rumen-protected methionine on milk yield and composition in dairy cows. Journal of Dairy Research 64, 173-179.

Chilliard, Y., Doreau, M., Gagliostro, G. \& Elmeddah, Y. (1993). Addition de lipides protégés (encapsulés ou savons de calcium) à la ration de vaches laitières. Effets sur les performances et la composition du lait (Protected (encapsulated or calcium salts) lipids in dairy cow diets. Effects on production and milk composition). INRA Productions Animales 6, 139-150.

Chilliard, Y., Gagliostro, G., Fléchet, J., Lefaivre, J. \& Sebastian, I. (1991b). Duodenal rapeseed oil infusion in early and midlactation cows. 5. Milk fatty acids and adipose tissue lipogenic activities. Journal of Dairy Science 74, 1844-1854.

Chilliard, Y., Vacelet, J. M., Durand, D. \& Bauchart, D. (1992). Portal-drained viscera (PDV) and hepatic production rates of energy metabolites in high yielding dairy cows. Effects of a fat supplement on PDV rates. Reproduction Nutrition Development 32, 501 Abstr.

Clinquart, A., Istasse, L., Dufrasne, I., Mayombo, A., Van Eenaeme, C. \& Bienfait, J. M. (1991). Effects on animal performance and fat composition of two fat concentrates in diets for growing-fattening bulls. Animal Production 53, 315-320.

Clinquart, A., Micol, D., Brundseaux, C., Dufrasne, I. \& Istasse, L. (1995). Utilisation des matières grasses chez les bovins à l'engraissement (Use of fat in fattening diets for cattle). INRA Productions Animales 8, $29-42$.

Cook, D. A., McGilliard, A. D. \& Richard, M. (1967). In vitro conversion of long-chain fatty acids to ketones by bovine rumen mucosa. Journal of Dairy Science 51, 715-720.

Cottyn, B. G., Buysse, F. X. \& Boucqué, C. V. (1971). The effect of linseed oil fatty acids on digestibility and rumen fermentation. Zeitschrift für Tierphysiologie, Tieremährung und Futtermittelkunde 27, $252-259$.

Demeyer, D. I., Henderson, C. \& Prins, R. A. (1978). Relative significance of exogenous and de novo synthesized fatty acids in the formation of rumen microbial lipids in vitro. Applied and Environmental Microbiology 35, 24-31.

Demeyer, D. I. \& Hoozee, J. (1984). Schatting van linolzuursintese in de pens van een schaap bij eiwiten vetvrije voedering (Estimated synthesis of linoleic acid in the rumen of a sheep fed a protein and fat free diet). 9de Studiedag voor Nederlandstalige Voedingsonderzockers, Utrecht, pp. 27-28.

Demeyer, D. I. \& Van Nevel, C. J. (1995). Transformations and effects of lipids in the rumen: three decades of research at Gent University. Archives of Animal Nutrition 48, 119-134.

Doreau, M. (1992). Effect of supplementation with hydrogenated fish oil on digestion in cows. Annales de Zootechnie 41, 137-143.

Doreau, M. \& Boulot, S. (1989). Recent knowledge on mare milk production: a review. Livestock Production Science 22, 213-235.

Doreau, M. \& Chilliard, Y. (1992). Influence d'une supplémentation de la ration en lipides sur la qualité du lait chez la vache (Fat supplementation in dairy rations and its consequences on milk quality in dairy cows). INRA Productions Animales 5, 103-111.

Doreau, M. \& Chilliard, Y. (1997). Effects of ruminal or postruminal fish oil supplementation on intake and digestion in dairy cows. Reproduction Nutrition Development 37, 113-124.

Doreau, M., Demeyer, D. I. \& Van Nevel, C. (1997). Transformations and effects of unsaturated fatty acids in the rumen. Consequences on milk fat secretion. In Milk Composition, Production and Biotechnology, pp. 73-92 [R. A. S. Welch, D. J. W. Burns, S. R. Davis, A. I. Popay and G. G. Prosser, editors]. Wallingford: CAB INTERNATIONAL.

Doreau, M. \& Ferlay, A. (1994). Digestion and utilisation of fatty acids by ruminants. Animal Feed Science and Technology 45, 379-396.

Doreau, M. \& Ferlay, A. (1995). Effect of dietary lipids on nitrogen metabolism in the rumen: a review. Livestock Production Science 43, 97-110.

Edmondson, L. F., Yoncoskie, R. A., Rainey, N. H., Douglas, F. W. Jr \& Bitman, J. (1974). Feeding encapsulated oils to increase the polyunsaturation in milk and meat fat. Journal of the American Oil Chemists' Society 51, 72-76.

Edwards, H. M. Jr \& Hart, P. (1971). Carcass composition of chickens fed carbohydrate-free diets containing various lipid energy sources. Journal of Nutrition 101, 986-996.

Eilmans, I. (1991). Fettverdauung beim Pferd sowie die Folgen einer marginalen Fettversorgung (Digestibility of fat in horses and the consequences of marginal fat supply). Inaugural Dissertation for Doctor of Veterinary Medicine, Hannover, Germany.

Elmeddah, Y., Doreau, M. \& Michalet-Doreau, B. (1991). Interaction of lipid supply and carbohydrates in the diet of sheep with digestibility and ruminal digestion. Journal of Agricultural Science, Cambridge 116, $437-445$.

Emmanuel, B. (1974). On the origin of rumen protozoan fatty acids. Biochimica et Biophysica Acta 337, $404-413$.

Enjalbert, F., Nicot, M. C., Vernay, M., Moncoulon, R. \& Griess, D. (1994). Effect of different forms of polyunsaturated fatty acids on duodenal and serum fatty acid profiles in sheep. Canadian Journal of Animal Science 74, 595-600.

Farnworth, E. R. \& Kramer, J. K. G. (1987). Fat metabolism in growing swine: a review. Canadian Journal of Animal Science 67, 301-318. 
Ferlay, A., Chabrot, J., Elmeddah, Y. \& Doreau, M. (1993). Ruminal lipid balance and intestinal digestion by dairy cows fed calcium salts of rapeseed oil fatty acids or rapeseed oil. Journal of Animal Science 71, 22372245.

Ferlay, A. \& Doreau, M. (1995). Influence of method of administration of rapeseed oil in dairy cows. 2. Status of divalent cations. Journal of Dairy Science 78, 2239-2246.

Fisher, C. (1984). Fat deposition in broilers. In Fats in Animal Nutrition, pp. 437-470 [J. Wiseman, editor]. London: Butterworths.

Ford, A. L., Park, R. J. \& Ratcliff, D. (1976). Effect of a protected lipid supplement on flavor properties of beef. Joumal of Food Science 41, 94-96.

Fotouhi, N. \& Jenkins, T. C. (1992). Resistance of fatty acyl amides to degradation and hydrogenation by ruminal microorganisms. Journal of Dairy Science 75, 1527-1532.

Freeman, C. P. (1994). The digestion, absorption and transport of fats: non-ruminants. In Fats in Animal Nutrition, pp. 105-122 [J. Wiseman, editor]. London: Butterworths.

Galbraith, H., Miller, T. B., Paton, A. M. \& Thompson, J. K. (1971). Antibacterial activity of long-chain fatty acids and the reversal with calcium, magnesium, ergocalciferol and cholesterol. Journal of Applied Bacteriology 34, 803-813.

Garnsworthy, P. C. (1996). The effects on milk yield and composition of incorporating lactose into the diet of dairy cows given protected fat. Animal Science 62, 1-3.

Garrett, W. N., Yang, Y. T., Dunkley, W. L. \& Smith, L. M. (1976). Increasing the polyunsaturated fat content of beef and lamb. Journal of Animal Science 42, 845-853.

Gerson, T., John, A. \& King, A. S. D. (1985). The effects of dietary starch and fibre on the in vitro rates of lipolysis and hydrogenation by sheep rumen digesta. Journal of Agricultural Science, Cambridge 105, 27-30.

Goering, H. K., Gordon, C. H., Wrenn, T. R., Bitman, J., King, R. L. \& Douglas, F. W. Jr (1976). Effect of feeding protected safflower oil on yield, composition, flavor and oxidative stability of milk. Journal of Dairy Science 59, $416-425$.

Goosen, P. C. M. (1975). Absorption of long-chain fatty acids by rumen epithelium: experiments in vivo and in vitro. Zeitschrift für Tierphysiologie, Tierernährung und Futtermittelkunde 35, 296-302.

Hagemeister, H. \& Kaufmann, W. (1979). Verdaulichkeit von Fettsäuren im Darm von Milchkühen (Digestibility of fatty acids in the intestine of dairy cows). Kieler Milchwirtschaftliche Forschungsberichte 31, 31-39.

Harfoot, C. G., Crouchman, M. L., Noble, R. C. \& Moore, J. H. (1974). Competition between food particles and rumen bacteria in the uptake of long-chain fatty acids and triglycerides. Journal of Applied Bacteriology 37 , 633-641.

Harfoot, C. G. \& Hazlewood, G. P. (1988). Lipid metabolism in the rumen. In The Rumen Microbial Ecosystem, pp. 285-322 [P. N. Hobson, editor]. London and New York: Elsevier Applied Science.

Harfoot, C. G., Noble, R. C. \& Moore, J. H. (1973). Food particles as a site for biohydrogenation of unsaturated fatty acids in the rumen. Biochemical Journal 132, 829-832.

Hegsted, D. M., Ausman, L. M., Johnson, J. A. \& Dallal, G. E. (1993). Dietary fat and serum lipids: an evaluation of the experimental data. American Journal of Clinical Nutrition 57, 875-883.

Hillard, B. L., Lundin, P. \& Clarke, S. D. (1980). Essentiality of dietary carbohydrate for maintenance of liver lipogenesis in the chick. Journal of Nutrition 110, 1533-1542.

Hogan, J. P., Connell, P. J. \& Mills, S. C. (1972). The digestion of safflower oil casein particles protected against ruminal hydrogenation in sheep. Australian Jourmal of Agricultural Research 23, 87-95.

Ikwuegbu, O. A. \& Sutton, J. D. (1982). The effect of varying the amount of linseed oil supplementation on rumen metabolism in sheep. British Journal of Nutrition 48, 365-375.

Jenkins, T. C. (1993). Lipid metabolism in the rumen. Journal of Dairy Science 76, 3851-3863.

Jenkins, T. C. (1995). Butylsoyamide protects soybean oil from ruminal biohydrogenation: effects of butylsoyamide on plasma fatty acids and nutrient digestion in sheep. Journal of Animal Science 73, 818-823.

Jenkins, T. C. \& Palmquist, D. L. (1984). Effect of fatty acids or calcium soaps on rumen and total nutrient digestibility of dairy rations. Journal of Dairy Science 67, 978-986.

Just, A. (1982a). The net value of crude fat for growing pigs. Livestock Production Science 9, 501-509.

Just, A. $(1982 b)$. The influence of crude fiber from cereals on the net energy value of diets for growth in pigs. Livestock Production Science 9, 569-580.

Kemp, P., Lander, D. J. \& Orpin, C. G. (1984). The lipids of the rumen fungus Piromonas communis. Journal of General Microbiology 130, 27-37.

Lebret, B., Lefaucheur, L., Mourot, J. \& Bonneau, M. (1996). Influence des facteurs d’élevage sur la qualité de la viande de porc (Effects of rearing factors on pig meat quality). In Journées de la Recherche Porcine en France vol. 28, pp. 137-156. Paris: Institut Technique du Porc.

Lessire, M. (1995). Qualité des viandes de volaille: le rôle des matières grasses alimentaires (Poultry meat quality: the role of dietary fats). INRA Productions Animales 8, 335-340.

Lessire, M., Doreau, M. \& Aumaître, A. (1996). Digestive and metabolic utilization of fats in domestic animals. In Oils and Fats Manual, A Comprehensive Treatise, pp. 703-714 [A. Karleskind, editor]. Paris: Lavoisier Publishing Intercept. 
Lessire, M. \& Leclercq, B. (1982). Metabolisable energy value of fats in chicks and adult cockerels. Animal Feed Science and Technology 7, 365-374.

Maczulak, A. E., Dehority, B. A. \& Palmquist, D. L. (1981). Effect of long-chain fatty acids on growth of rumen bacteria. Applied and Environmental Microbiology 42, 856-862.

Martin, B. \& Coulon, J. B. (1995). Facteurs de production du lait et caractéristiques des fromages. I. Influence des facteurs de production sur l'aptitude à la coagulation des laits de troupeaux (Milk production and cheese characteristics. I. Influence of milk production conditions on herd milk clotting ability). Lait 75, 61-80.

Melton, S. L. (1990). Effects of feeds on flavor of red meat: a review. Journal of Animal Science 68, 44214435 .

Mietton, B. (1991). La standardisation des laits de fromagerie (Standardization of cheese milk). In Proceedings of the XXIII International Dairy Congress, Montréal, vol. 3, pp. 1838-1863. Brussels: International Dairy Federation.

Middaugh, R. P., Baer, R. J., Casper, D. P., Schingoethe, D. J. \& Seas, S. W. (1988). Characteristics of milk and butter from cows fed sunfiower seeds. Journal of Dairy Science 71, 3179-3187.

Moore, J. H. \& Christie, W. W. (1984). Digestion, absorption and transport of fats in ruminant animals. In Fats in Animal Nutrition, pp. 123-149 [J. Wiseman, editor]. London: Butterworths.

Morgan, C. A., Noble, R. C., Cocchi, M. \& McCartney, R. (1992). Manipulation of the fatty acid composition of pig meat lipids by dietary means. Journal of the Science of Food and Agriculture 58, 357-368.

Mourot, J., Aumaître, A. \& Mounier, A. (1992). Interaction entre vitamine $\mathbf{E}$ et acide linoléique sur la composition de la carcasse, la qualité et la conservation des lipides de la viande chez le porc (Interaction between dietary contents of vitamin $\mathrm{E}$ and linoleic acid on carcass composition and quality of lipids in stored pig meat). Sciences des Aliments 12, 743-755.

Mourot, J., Peiniau, P. \& Mounier, A. (1994). Effets de l'acide linoléique alimentaire sur l'activité des enzymes de la lipogenèse dans les tissus adipeux chez le porc (Effect of dietary linoleic acid on lipogenesis in adipose tissue of pig). Reproduction Nutrition Development 34, 213-220.

Noble, R. C. (1996). Manipulating the fatty acid composition of pig and poultry products. Animal Science 73, 639 Abstr.

Opstvedt, J. (1984). Fish fats. In Fats in Animal Nutrition, pp. 53-83 [J. Wiseman, editor]. London: Butterworths.

Ottou, J. F., Doreau, M. \& Chilliard, Y. (1995). Duodenal infusion of rapeseed oil in midlactation cows. 6. Interaction with niacin on dairy performance and nutritional balance. Journal of Dairy Science 78, 13451352.

Ouhayoun, J., Kopp, J., Bonnet, M., Demarne, Y. \& Delmas, D. (1987). Influence de la composition des graisses alimentaires sur les propriétés des lipides périrénaux et la qualité de la viande du lapin (Influence of dietary fat composition on rabbit perirenal lipids properties and meat quality). Science des Aliments $7,521-$ 534.

Palmquist, D. L. (1988). The feeding value of fats. In Feed Science, pp. 293-311 [E. R. Ørskov, editor]. Amsterdam: Elsevier.

Palmquist, D. L., Beaulieu, A. D. \& Barbano, D. M. (1993). Feed and animal factors influencing milk fat composition. Journal of Dairy Science 76, 1753-1771.

Palmquist, D. L. \& Jenkins, T. C. (1980). Fat in lactation rations: a review. Journal of Dairy Science 63, 1-14.

Palmquist, D. L., Jenkins, T. C. \& Joyner, A. E. (1986). Effect of dietary fat and calcium source on insoluble soap formation in the rumen. Journal of Dairy Science 69, 1020-1025.

Palmquist, D. L. \& Moser, E. A. (1981). Dietary fat effects on blood insulin, glucose utilization, and milk protein content of lactating cows. Journal of Dairy Science 64, 1664-1670.

Pennington, J. A. \& Davis, L. (1975). Effects of intraruminal and intra-abomasal additions of cod-liver oil on milk fat production in the cow. Journal of Dairy Science $\mathbf{5 8}, 49-55$.

Poste, L. M. (1990). A sensory perception of effects of feeds on flavor in meats: poultry meats. Journal of Animal Science 68, 4414-4420.

Remeuf, F., Cossin, V., Dervin, C., Lenoir, J. \& Tomassone, R. (1991). Relations entre les caractéristiques physico-chimiques des laits et leur aptitude fromagère (Relationships between physico-chemical characteristics of milks and their cheese-making properties). Lait 71, 397-421.

Roger, V., Fonty, G., Komisarczuk-Bony, S. \& Gouet, P. (1990). Effects of physicochemical factors on the adhesion to cellulose Avicel of the ruminal bacteria Ruminococcus flavefaciens and Fibrobacter succinogenes subsp. succinogenes. Applied and Environmental Microbiology 56, 3081-3087.

Schauff, D. J. \& Clark, J. H. (1989). Effects of prilled fatty acids and calcium salts of fatty acids on rumen fermentation, nutrients digestibilities, milk production, and milk composition. Journal of Dairy Science $\mathbf{7 2}$, 917-927.

Sheehy, P. J. A., Morrissey, P. A., Buckley, D. J. \& Frigg, M. (1993). Lipid oxidation and dietary vitamin E supplementation in broilers. In Quality of Poultry Meat, pp. 380-388 [P. Colin, J. Culioli and F. H. Ricard, editors]. Tours, France: WPSA.

Smith, W. A., Harris, B. Jr, Van Horn, H. H. \& Wilcox, C. J. (1993). Effects of forage type on production of dairy cows supplemented with whole cottonseed, tallow, and yeast. Journal of Dairy Science 76, $205-215$. 
Stahly, T. S. (1984). Use of fats in diets for growing pigs. In Fats in Animal Nutrition, pp. 313-331 [J. Wiseman, editor]. London: Butterworths.

St John, L. C., Young, C. R., Knabe, D. A., Thompson, L. D., Schelling, G. T., Grundy, S. M. \& Smith, S. B. (1987). Fatty acid profiles and sensory and carcass traits of tissues from steers and swine fed an elevated monounsaturated fat diet. Journal of Animal Science 64, 1441-1447.

Storry, J. E., Brumby, P. E. \& Dunkley, W. L. (1980). Influence of nutritional factors on the yield and content of milk fat: protected non-polyunsaturated fat in the diet. International Dairy Federation Bulletin 125, $105-125$.

Storry, J. E., Brumby, P. E., Hall, A. J. \& Johnson, V. W. (1974). Response of the lactating cow to different methods of incorporating casein and coconut oil in the diet. Journal of Dairy Science 57, 61-67.

Sukhija, P. S. \& Palmquist, D. L. (1990). Dissociation of calcium soaps of long-chain fatty acids in rumen fluid. Journal of Dairy Science 73, 1784-1787.

Sundstøl, F. (1974). Hydrogenated marine fat as feed supplement. III. Digestibility of rations containing hydrogenated marine fat in sheep. Meldinger fra Norges Landbrukshogskole 161, $31 \mathrm{pp}$.

Tesfa, A. T., Tuori, M. \& Syrjala-Qvist, L. (1992). The influence of partial replacement of barley with dietary fat sources on growth and feed conversion efficiency of growing bulls. Agricultural Science in Finland 1, 267-278.

Toullec, R. \& Mathieu, C. M. (1969). Utilisation digestive des matières grasses et de leurs principaux acides gras par le veau préruminant à l'engrais; influence sur la composition corporelle (Digestive utilization of fats and their principal fatty acids by fattening preruminant calves. Influence on body composition). Annales de Biologie Animale, Biochimie et Biophysique 9, 139-160.

Touraille, C., Valin, C., Aurousseau, B., Sornay, J. \& Bayle, M. C. (1983). Influence du mode de production sur la qualité de la viande de veau (Influence of calf production system on the quality of veal). Bulletin Technique CRZV Theix, INRA 54, 43-47.

Van der Honing, Y., Wieman, B. J., Steg, A. \& Van Donselaar, B. (1981). The effect of fat supplementation of concentrates on digestion and utilization of energy by productive dairy cows. Netherlands Journal of Agricultural Science 29, 79-92.

Van Nevel, C. J. \& Demeyer, D. I. (1995). Lipolysis and biohydrogenation of soybean oil in the rumen in vitro: inhibition by antimicrobials. Journal of Dairy Science 78, 2797-2806.

Van Nevel, C. J. \& Demeyer, D. I. (1996a). Influence of pH on lipolysis and biohydrogenation of soybean oil by rumen contents in vitro. Reproduction Nutrition Development 36, 53-63.

Van Nevel, C. J. \& Demeyer, D. I. (1996b). Effect of $\mathrm{pH}$ on biohydrogenation of polyunsaturated fatty acids and their Ca-salts by microorganisms in vitro. Archives of Animal Nutrition 49, 151-158.

Vermorel, M., Sauvant, D. \& Michalet-Doreau, B. (1986). Valeur énergétique des matières grasses de la ration des vaches laitières (Energy value of dietary fats in dairy cows). Bulletin Technique CRZV Theix, INRA 66, 67-73.

White, T. W., Grainger, R. B., Baker, F. H. \& Stroud, J. W. (1958). Effect of supplemental fat on digestion and the ruminal calcium requirement of sheep. Journal of Animal Science 17, 797-803.

Willett, W. C., Stampfer, M. J., Manson, J. E., Colditz, G. A., Speizer, F. E., Rosner, B. A., Sampson, L. A. \& Hennekens, C. H. (1993). Intake of trans fatty acids and risk of coronary heart disease among women. Lancet 341, 581-585.

Wiseman, J. (1984). Assessment of the digestible and metabolizable energy of fats for non-ruminants. In Fats in Animal Nutrition, pp. 277-297 [J. Wiseman, editor]. London: Butterworths.

Wong, N. P., Walter, H. E., Vestal, J. H., Lacroix, D. E. \& Alford, J. A. (1973). Cheddar cheese with increased polyunsaturated fatty acids. Journal of Dairy Science 56, 1271-1275.

Wong, W., Jelen, P. \& Deman, J. M. (1982). Softening of butter related to feeding low doses of protected tallow supplement. Journal of Dairy Science 65, 1632-1638.

Wood, J. D. (1984). Fat deposition and the quality of fat tissue in meat animals. In Fats in Animal Nutrition, pp. 407-435 [J. Wiseman, editor]. London: Butterworths.

Wood, J. D., Buxton, P. J., Whittington, F. M. \& Enser, M. (1986). The chemical composition of fat tissues in the pig: effects of castration and feeding treatment. Livestock Production Science 15, 73-82.

Wood, R. D., Bell, M. C., Grainger, R. B. \& Teekel, R. A. (1963). Metabolism of labelled linoleic- $1-{ }^{14} \mathrm{C}$ acid in the sheep rumen. Journal of Nutrition 79, 62-68.

Wu, Z. \& Huber, J. T. (1994). Relationship between dietary fat supplementation and milk protein concentration in lactating cows: a review. Livestock Production Science 39, 141-155.

Zinn, R. A. (1989). Influence of level and source of dietary fat on its comparative feeding value in finishing diets for feedlot steers: metabolism. Journal of Animal Science 67, 1038-1049. 